\title{
The 18th World Congress of Dermatology
}

\section{Ichiro Kikuchi}

(National Leprosarium Kikuchi Keifu-En)

The 18th World Congress of Dermatology was held in New York in June 1992, during which a symposium on leprosy was chaired by Dr. Bhutani of India. He characterized the spectrum of leprosy and stated that leprosy patients in the world num bered 20 to 15 million, as against the $5,500,000$ by a WHO report. Azulay of Brazil proposed a concept of the third type of leprosy reaction with auto. immune antibodies following type 1 and type 2 reactions of Jopling. This has aroused a considerable discussion.

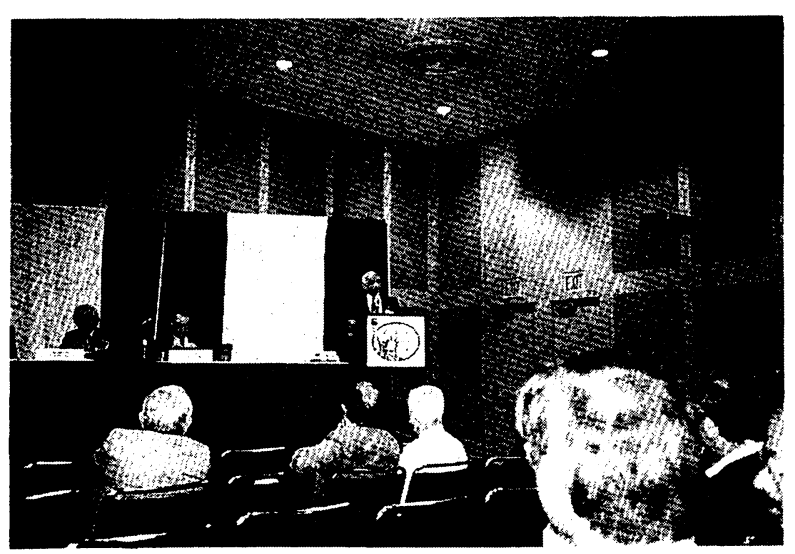

第18回世界皮膚科総会「らい」シンポジウム

ブタニ教授発表中

\section{第18回世界皮膚科総会出席記}

\section{菊 池 一 郎}

\section{国立療養所菊池惠楓園}

平成 4 年 6 月, ニューヨークでおこなわれた世 界皮膚科総会のらいのシンポジウムを聞く機会に 恵まれたので，その感想を述べてみたい。筆者は らいは初心者で, らいの国際学会出席も初めてで あり，英語も不十分であるので的外れの発言があ ることをお許し願いたい。

世界皮膚科総会は 5 年に 1 回催され，10年前は 東京, 5 年前はベルリンで行われた。いずれの場 合も数千名も出席し盛会であった。二ューヨーク 市は治安が悪いので悪名高く, 出席者には学会本
部から危険な所には行くなとか、タクシーの乗り 方にいたるまで色々注意と警告の手紙が舞い込ん だ。

戦々敚々として出かけたわけは，学会のある ジャビッツ・コンベンション・センターはハドソ ン川に面した数ブロックにもわたる巨大な建物で あるが，そこは治安の悪い８番街のまっただなか であるからである。どうもニューヨーク市当局は これらの建物を建て，この部分の再開発を図って いるようである。 
らいのシンポジウムは 6 月 12 日に始まった学会 の最終日に近い17日の水曜日であった。広い講堂 でシンポジウムは厳肃に行われた。

\section{らいのシンポジウムのプログラム}

1. Spectral concept of leprosy

Lalit K. Bhutani, India

2. Reactions in leprosy, clinical aspects

Rubem D. Azulay, Brazil

3. Reaction in leprosy

Bernard Naafs, the Netherlands

4. Cytokins in leprosy

Robert L. Modlin, USA

5. Experimental chemotherapy

D. K. Banerjee, England

6. Multi-drug therapy in leprosy

Jose Terecio de las Aguas, Spain

7. An overview of leprosy research at Carville

Robert C. Hastings, USA

8. Conclusions

Lalit K. Bhutani, India

\section{司会者ブタ二教授}

ブタ二教授は有名ならい学者で何度も来日して いるし，論文も多い。司会者でもあるが，らいの 一般的な話と病型の話を格調高い英語で講演し た。彼はハンセン病という言葉の使用には反対で あった。ハンセンはこの病気に罹患したわけでも なく, 病原菌でもないからである。しかし, lep er（らい患者，つまはじきされる人という意味も ある）という言葉は我々はこの会場から出たら使 うべきでないと力説した。らい患者の統計で本年 WHOから発表されたのは550万という数字がある が1)，ブタ二教授は2000万ないし1500万という数 字を挙げていた。どうもWHOの方はMDTを買い かぶりすぎる傾向がある。インドの患者統計でブ 夕二教授は400万，WHOのほうは300万と数がえ らくおおざっぱである。アジア，アフリカ，南ア メリカの 3 大州で患者の $99 \%$ が住んでいるとも いった。

T型はホストの菌に対する抵抗が強く, 逆にホ ストが強く破壞されるのにたいし, L型はその逆 である。ブタ二教授はТ型に第 2 次世界大戦で
ロッテルダム，アムステルダム，レニングラード， ロンドンなどが強く抵抗し街が徹底的に破壊され たことを，その逆のL型を抵抗せず破壊されな かったパリに譬えたのは面白かった。感染症で大 事なパラサイト，環境，ホストについて我々はよ く知らない, 特に菌の培養もできていないのは恥 である，ブッシュ大統領はもっとらいの研究に予 算を使うべきであると発言し，感銘深い講演を終 えた。患者の数から言えばインドはらいの大国で ある。ここの人の意見はよく拝聴する必要がある。

\section{自己免疫問答}

ジョップリングの教科書でもらいの 1 型反応と 2 型反応は有名である。ブラジルのアズレイ博士 は自己抗体があるらい患者を第 3 の反応という主 張を述べられた。世界の通説になっていないが， 議論が沸騰したところである。しかし，よく聞い てみるとSLEなど自己免疫患者とらいの合併とも 考えられる。色々質疑応答もあったが，どうも結 論がつかなかった。セッションが終わって私は, 単なる合併ではないかと個人的に質問したが，治 療上このようにした方が役に立つという話であっ た。私はあまり経験はないが，それでもらい患者 にDLEを合併しているのは経験がある。自己抗体 をつくるのであるから下型かどうか質問すればよ かったと悔やまれた。

\section{その他}

サイトカインの話はむつかしかったが，らいは 免没学者には興味ある対象に違いない。

化学療法の話ではオフロキサシンだけでなくク ラリスロマイシン (マクロライド系) やミノサイ クリンが有効のようであるが，実際多数の患者を つかった臨床統計ではなかった。今後の発表を期 待したい。

スペインからのMDTの話には興味があったが, あいにくスペイン語であったのでさっぱりわから なかった。ヘースティングス博士はカービルで行 われているリサーチ（いまはルイジアナ州立大学 に移転したという）の説明をされたが動物の管理 などにも言及され，獣医や管理者なども感謝され ていた。大研究所ともなるといろいろな人が協力 していることがわかった。もっともあまり興味を 
ひかなかったので討論はなかった。

あちこちでENLの話がいろいろでたが，ENLの 命名者が日本人の村田博士であるということをい おうと思ったが，発言する時間がなくて残念で あった。光田先生, 阿部先生なども日本が誇る先 達である。らいとエイズとの討論も少しあった。

\section{難しい免疫学}

つぎの特別講演はBarry R. Bloom博士の1992年 におけるらい，根絶にむかっての展望と可能性

(Leprosy 1992 : Prospects and potential for eradication）の題はえらく高尚で魅力的だが内容 はまったく免疫学そのものでさっぱりわからな かった。

私信でJopling博士にこれはむつかしかったと書 いたらこのように論された。

You make an understatement when you say that immunolgy is difficult to understand; I have attended lectures by immunologists and have been completely uninformed, as completely as if I had listened to a foreign language. The trouble is that one has to be an immunologist to enjoy a lecture or a paper from an immunologist.
それで博士の教科書の免疫学の所は免疫学者にま かせなかったという。

学会というとどうも学者の話を聞くばかりとい う傾向があるのは残念である。臨床家の実際的な 話を聞いてみたかった。ポスターセッションもら いがでていたし, 症例報告もあったようであるが, ばらばらでまとまりがなかった。ポス夕ーは毎日 張り替えられ討論はなかった。（展示している人 がそこにおれば討論するわけではあるが）内容も 玉石混交といった具合いでなんとなく欲求不満が 残った。

シンポジウムの終わりにカービルをいつか訪問 したいとへースティングス博士に挨拶をして会場 をあとにした。

(原稿の依頼があとにきたので、たまたま購入し ていたシンポジウムの録音テープを再度聞いた。 コメントをいただいたジョップリング博士に感謝 する。)

\section{文 献}

1) Noordeen, S. K. et al. Bull. WHO, 70: 7-10, 1992. 